\title{
MPs' Principals and the Substantive Representation of Disadvantaged Immigrant Groups
}

\author{
Lucas Geese $^{a}$ and Carsten Schwemmer ${ }^{b}$ \\ ${ }^{a}$ Faculty for Social Sciences, Economics, and Business Administration, University of Bamberg, Bamberg, \\ Germany, Lucas.Geese@uni-bamberg.de (Corresponding author); ${ }^{b}$ Faculty for Social Sciences, Economics, \\ and Business Administration, University of Bamberg, Bamberg, Germany, Carsten.Schwemmer@uni- \\ bamberg.de
}

\begin{abstract}
This paper provides an alternative understanding of the substantive representation of immigrant-origin citizens than previous work in the "politics of presence" tradition. Instead of assuming members of parliaments' (MPs) intrinsic motivations to be underlying immigrants' substantive representation, we highlight extrinsic motives. Drawing on principal-agent theory, we conceptualise MPs as delegates who follow the instructions of their main principals, constituents and party bodies. On this basis, we study the link between institutional variables and substantive representation. Based on an analysis of more than 20,000 parliamentary questions for written answer tabled in the 17th German Bundestag (2009-13), we find that immigrants' substantive representation hinges strongly on the demands of MPs' principals. However, our empirical analysis suggests that electoral rules do not influence the relationships between MPs and their principals, while candidate selection methods as well as powerful parliamentary party group leaderships do.
\end{abstract}

\section{Keywords}

Substantive representation; Immigrant-origin citizens; Parliamentary questions; Bundestag; Germany; Parliamentary institutions

\section{Acknowledgments}

Earlier versions of this article were presented at the ABC Conference 2016 in Bamberg and at the “Anxieties of Democracy” workshop 2017 in Mainz. We thank Henning Bergmann, Javier Martínez Cantó, Jorge M. Fernandes, Simon Fink, Daniel Gillion, Marc Helbling, Margret Hornsteiner, Stefanie John, Ira Katznelson, Thomas Saalfeld and Caroline Schultz for helpful comments and suggestions. We also thank Magdalena Stiegler, Elena Maier, David Beck, Johannes Geiger and Emanuel Slany for research assistance.

\section{Funding}

This work was supported by the German Research Foundation (DFG) under Grant SA 2160/3-1 


\section{Introduction}

The normative ideal of democratic representation (e.g. Dahl 1971) suggests that as more immigrant-origin residents acquire citizenship and thus the right to vote, their interests should find more consideration in the parliamentary activities of members of parliament (MPs). Indeed, the relevance of this ideal should not be underestimated, given that immigrants and their descendants remain socially and economically disadvantaged in most Western democracies of immigration (Alba and Foner 2015). Consequently, political scientists are called for to examine the mechanisms underlying the substantive representation of disadvantaged immigrant groups.

Conceptually, substantive representation refers to whether MPs "act in the interest of" citizens, while descriptive representation refers to whether MPs' sociodemographic features "stand for" a certain group of citizens (Pitkin 1967). Despite this conceptual differentiation, however, normative claims of a connection between the two concepts of representation (Mansbridge 1999; Phillips 1995) has inspired the lion's share of previous research on immigrants' substantive representation (e.g. Aydemir and Vliegenthart 2016; Hänni 2017; Saalfeld 2011; Saalfeld and Bischof 2013; Wüst 2014a). Doubtlessly, this literature has advanced our understanding considerably, confirming by and large a link between the descriptive and substantive representation of immigrant-origin citizens. Nevertheless, it is no secret that immigrant-origin citizens remain descriptively underrepresented in Western European parliaments (Alba and Foner 2015; Bird, Saalfeld, and Wüst 2011; Bloemraad and Schönwälder 2013). Therefore, this group of citizens has to rely by large on the level of substantive representation provided by native MPs. There is, however, a dearth of research on immigrants' substantive representation unrelated to MPs' own national or ethnic backgrounds. 
Consequently, rather than relying on the assumption of intrinsically motivated "descriptive" MPs, we think in this paper of MPs as delegates who act based on the instructions of their most important principals: local voters as well as political party bodies inside and outside parliament (Carey 2009; Strøm 2000). Speaking on behalf of immigrants and their descendants is understood as being part of MPs' strategies to please the demands of their principals. Yet, the incentive to please the demands of one principal at the expense of another one is a function of the institutional environment. On one hand, MPs favour the demands of a centralised party body under party-centred electoral rules, a centralised candidate selection method and due to powerful parliamentary party groups (PPGs). On the other, they are "pulled" towards local demands by candidate-centred electoral rules and a localised candidate selection method (Carey and Shugart 1995; Gallagher 1988; Strøm 1997).

The question arises what happens when the incentives encoded in these institutional features conflict (Martin 2014; Preece 2014). Do MPs remain responsive to the local demands of immigrant-origin citizens when a decentralised candidate selection method clashes with partycentred electoral rules? Do they remain responsive to the demands of the PPG leadership when electoral rules are candidate-centred? To examine these questions, we turn to a case study of MPs' legislative behaviour in the German Bundestag, a complex institutional context combining mixed electoral rules with a localised candidate selection method and tightly organised PPGs. Here, MPs are "pulled” by their principals' demands in different directions, thus providing researchers the opportunity to better disentangle the effects of institutional variables while holding country-specific context fixed. Empirically, this study is based on a dataset of all MPs serving in the $17^{\text {th }}$ Bundestag (2009-13), combined with a semi-automated content analysis of more than 20,000 of their parliamentary questions (PQs) for written answer. 
Quantitative analyses of this dataset show that principals' demands are important determinants of the substantive representation of disadvantaged immigrant groups in MPs' PQs. However, our findings provide little support that different electoral rules moderate MPs' attentiveness towards the demands of their principals. A localised candidate selection on the one hand and powerful PPG leaderships on the other, by contrast, are found to be more consequential for the substantive representation of disadvantaged immigrant groups.

\section{Institutional Context and the Substantive Representation of}

\section{Disadvantaged Immigrant Groups}

A major controversy in political science is the question of whether MPs should be conceptualised as trustees, who act based on their own consciousness, or as delegates, who act based on the instructions of others (Andeweg and Thomassen 2005; Converse and Pierce 1986; Pitkin 1967). Conceptualising MPs as trustees means in large parts to assume that MPs' intrinsic motivations underlie their legislative behaviour. This is basically what normative arguments in the "politics of presence" school of thought are based on. In order to represent the interests of disadvantaged groups, representatives need to have a thorough understanding of and similar life experiences to the represented, which can be best achieved by descriptive representation (Mansbridge 1999; Phillips 1995:159). Previous empirical research in this line of thought (e.g. Aydemir and Vliegenthart 2016; Hänni 2017; Saalfeld 2011; Saalfeld and Bischof 2013; Wüst 2014a) is thus widely based on the assumption that MPs' legislative behaviour hinges on their intrinsic motivations, that is, on the trustee notion of substantive representation.

Conceptualising MPs as delegates, however, makes us aware that substantive representation may also be based on demands external to MPs' consciousness and personal experiences. In 
this view, MPs act as agents of principals who control access to certain goods that MPs value (Carey 2009; Strøm 2000). The assumption is that MPs are driven by their ambition to reach certain career related goals, ordered in the following way. First of all, MPs need to achieve reselection as a necessary precondition for their second goal, reelection, which in turn is a necessary condition for the achievement of their third goal, access to positions of influence within parliament, such as committee chairs or front-bench membership (Strøm 1997). The achievement of the first goal, reselection, is in most parliamentary democracies controlled by parties' nomination conventions (Müller 2000). The second goal, reelection, can only be achieved, if enough voters support the candidate or the party list bearing him/her (Mitchell 2000). And the third goal, positions of legislative influence, is in most cases under control of the leadership of the PPG (Carey 2009). Thus, MPs typically find themselves in the difficult situation of having to please the demands of (at times) three different principals: voters, party selectorates and PPG leaders.

In the view of principal-agent theory, MPs' acting on behalf of disadvantaged immigrant groups can be therefore understood as being part of a strategy supposed to please the demands of one or several principals. The extent to which the demands of one principal outweigh the demands of another one, however, depends on the relative value of the resources that are controlled by each principal, which is determined by the rules of the game, that is, their institutional environment (cf. Carey 2009:14). Among the most important institutional variables are electoral rules, candidate selection methods and the internal organisation of parliaments.

Electoral rules, to begin with, are commonly thought to determine how much local voter groups weigh in light of MPs' reelection prospects relative to the weight of the party branch controlling the candidate selection process. Under closed-list PR elections, voters have little leverage to change the electoral fate of individual candidates, given they are confronted with 
fixed and often long lists of candidates, which voters can only take or defect as a whole (Carey and Shugart 1995; Mitchell 2000). The list position allocated in the selection process will thus literally determine MPs' future electoral prospects, such that MPs should have strong incentives to follow the demands of a party selectorate (Carey 2009). By contrast, in more candidate-centred systems, like single-member district elections, voters have more influence over the electoral fate of individual candidates, such that MPs should cultivate a relatively stronger local voter support (Carey and Shugart 1995). Therefore, MPs should see more reasons to provide substantive representation in response to local concentrations of immigrant-origin citizens when elected in single-member districts. To the contrary, the demands of national party bodies should weigh stronger on MPs' shoulders with regard to the representation of immigrants' interests under closed-list PR rules.

The candidate selection method is another factor that can be plausibly assumed to affect the relationship between MPs and their principals. As already mentioned, reselection is a necessary precondition for all other career-related goals, such that MPs can be assumed to owe part of their loyalty to the gatekeepers in the candidate selection process (Müller 2000). In this respect, the degree of territorial decentralisation is an important dimension of candidate selection (Rahat and Hazan 2001). Arguably, local party organisations should attach greater weight to the local visibility of their parliamentary representatives while national party headquarters should value MPs' efforts to cultivate a national party reputation (Gallagher 1988:15; Karlsen and Narud 2013). Given the reputation and visibility of national MPs, their legislative behaviour should serve local party branches as an important campaigning tool for the purpose of tapping on local voter markets of immigrant-origin citizens in municipality elections. If local party branches have leverage over the reselection of MPs, they possess a means to that end, that is, the means to make their parliamentary agents speak on behalf of disadvantaged immigrant groups. Thus, the link between local concentrations of immigrantorigin citizens and their substantive representation may be the result of a localised candidate 
selection method. On the other hand, if the national party headquarters maintain control over the reselection of MPs, the demand of this principal should determine immigrants' substantive representation more strongly.

A third institutional factor, the internal organisation of parliaments, entails that MPs are agents of their PPG leaderships. In order to make parliamentary decision-making work, parliaments are complex and tightly organised institutions ensuring vertical and horizontal coordination of MPs' legislative activities (Cox 2006). Vertical coordination is typically provided by hierarchically organised PPGs, through which the leadership remains informed about backbenchers' legislative activities, controls their access to positions of influence, and has also the possibility to impose sanctions on them (Aldrich 1995; Saalfeld and Strøm 2014; Strøm 1997). Horizontal coordination cuts across this vertical hierarchy through policyspecialised committees entailing a division of labour between MPs (Mattson and Strøm 1995). However, due to the tight vertical organisation of PPGs in most parliamentary democracies, vertical and horizontal coordination interact. That is, the vertical grip of PPG leaders over MPs' legislative activities reach down into their committee work (Cox and McCubbins 1993; Damgaard 1995; Strøm 1998). Therefore, MPs have incentives to cater the interests of their PPGs through policy specialisation in a wide range of legislative activities. Thus, if the substantive representation of immigrant-origin citizens is in the interest of their PPGs, MPs should chose to please this demand with the repertoire of legislative activities available to them. 


\section{MPs, their Principals and the Substantive Representation of}

\section{Disadvantaged Immigrant Groups in the German Bundestag}

To put this theoretical framework to the test, we focus on Germany for two main reasons.

First, Germany is a very relevant case to the study of immigrants' substantive representation.

Germany accounts for $20 \%$ of the entire immigrant population in the European Union (OECD and EU 2015:40) and the immigrant-origin electorate is sizeable, amounting to $9 \%$ in the 2013 Bundestag elections (Bundeswahlleiter 2013). At the same time, however, there are strong structural inequalities separating immigrants' social and economic situations from those of the German majority population (cf. Die Beauftragte der Bundesregierung für Migration, Flüchtlinge und Integration 2016).

Second, Germany's institutional environment offers the opportunity to analyse and contrast the effects of institutional variables on the relationship between MPs and their principals. German MPs find themselves in a complex institutional environment combining mixed electoral rules with a localised candidate selection procedure and tightly organised PPGs. This environment provides researchers the opportunity to better disentangle the effects of these factors while holding constant influences of country-specific context (e.g. Moser and Scheiner 2012:46).

Indeed, it remains a matter of controversy whether electoral rules trump the effects of candidate selection methods and legislative organisation, or vice versa. Shugart and coauthors (2005, p. 441) argue, for example, that parties and MPs alike respond mainly to voters' informational demands encoded in the electoral system, and not, for example, to party-related candidate selection procedures. However, others have argued that centralised candidate selection methods and powerful PPG leaders make MPs have weaker constituency relations 
despite strong personal vote-seeking incentives encoded in electoral rules (Martin 2014; Preece 2014). In this article, we take these opposing views as an empirical question leveraging Germany as an institutional environment in which principals "pull” their MPs into different directions.

In Germany’s electoral system, 299 MPs are elected in single-member plurality districts (SMD tier), and a slightly larger number of MPs is elected in 16 multi-member districts under rules of closed-list proportional representation (PR tier). Thus, there is within-country variation in electoral rules. At the same time, however, candidates are selected in a strongly localised fashion. Formally, the electoral law stipulates that candidates in the SMD tier must be selected in local constituencies while candidates in the PR tier must be selected by nomination conferences at the upper regional level (Detterbeck 2016). However, the electoral law permits candidates to run as "double candidates", that is, in both electoral tiers simultaneously. In fact, double candidacy is very common practice, because voters reward parties electorally for the local presence of candidates (Ferrara, Herron, and Nishikawa 2005; Hainmueller and Kern 2008). Therefore, parties have vote-seeking incentives to require that their candidates are selected in the SMD tier before being allowed access to promising party list positions in the PR tier (Detterbeck 2016; Manow 2013:289). In the legislative period under study (2009-13), for instance, $96 \%$ of MPs elected in the PR tier were elected as double candidates and therefore encountered a selection process that started with their selection at the local level. In other words, as local re-selection is a precondition for realistic list positions in the PR tier, local reselection is de-facto a requirement for MPs' reelection in both electoral tiers.

The combination of varying electoral rules and a localised candidate selection process helps disentangling the effects of the underlying incentives to speak on behalf of immigrants and their descendants. Specifically, in line with Crisp, we argue that the finding of behavioural 
homogeneity across electoral tiers can be taken as evidence that the incentives institutionalized in the electoral tiers are being trumped by the candidate selection process (Crisp 2007:1462). In other words, if the locus of candidate selection is the driving force behind German MPs' responsiveness to the demands of local immigrant-origin citizens and not their election in single-member districts, then MPs should respond to the share of immigrant-origin citizens in the constituency where they were locally selected. Thus, our first hypothesis reads:

H1: MPs are more responsive to immigrant-origin citizens' interests the more immigrantorigin voters reside in their local constituencies, regardless of their election mode.

To the contrary, by following the argument that MPs' responsiveness to local demands is mainly determined by the personal vote-seeking incentives encoded in different electoral rules, a second hypothesis can be derived:

H2: MPs are more responsive to immigrant-origin citizens' interests the more immigrantorigin voters reside in their local constituencies, conditional on their election in a singlemember district.

MPs' responsiveness to the demands of their PPG leaderships is influenced by the way parliament is organised. In this regard, the Bundestag is a paradigmatic case of a partycontrolled Arbeitsparlament ("working parliament") based on the division of labour in policyspecialised committees (Miller and Stecker 2008). Indeed, given that there are almost ten times more committee meetings than plenary meetings throughout a legislative term, committees are the backbone of German MPs' legislative activities (Ismayr 2012:162). However, PPG leaderships maintain strong control of their MPs' committee work, as they have the prerogative of assigning MPs to, and withdrawing them from committees (Damgaard 1995; Miller and Stecker 2008). The strong control of parties is reflected in the fact that 
committees work behind closed doors, therefore only visible to the PPG leadership as a principal. Party control is further ensured by weekly held meetings of PPGs' working groups mirroring the committee structure for the purpose of before-committee meeting coordination (Miller and Stecker 2008). Accordingly, we argue that MPs are supposed to serve their PPGs as delegates in their committees as well as in remaining legislative activities by representing the official position of the national party. If they refuse to represent that position, the PPG leadership can apply several means of sanctioning. These range from subtle persuasion and threats, to the withdrawal of the committee seat, to the ultimate denial of upward promotion within the hierarchy of the PPG (Damgaard 1995; Ismayr 2012:169).

Empirically, we thus expect PPG leaderships' influence on the substantive representation of disadvantaged immigrant groups to be reflected in an interaction between MPs' committee assignment and parties' policy programmes. As MPs' policy-specialisation is reflected in their committee assignments, they should be more likely to engage in the substantive representation of immigrant-origin citizens if they sit on committees more likely to deal with matters of immigrants' disadvantage, for example on the committee for social affairs or education rather than on the committee for environment or defence. However, the influence of the committee assignment is contingent on the national policy programmes of their parties. Here, it is plausible to assume that left-leaning party programmes are more inclined to improve the living conditions of immigrants and their descendants than right-leaning party programmes (Bird et al. 2011; Messina 2007). To borrow the words of Anthony Messina, "the left's traditional policy agenda tends to dovetail with the perceived interests of immigrants. Specifically, the proclivity of the left to privilege the goals of full employment, greater socioeconomic equality, universal health care, a vibrant public educational system, racial equality and so on intersects with the material and subjective aspirations of immigrant voters who generally find themselves socioeconomically disadvantaged or the objects of racial prejudice or social exclusion" (Messina 2007:208). 
Our third hypothesise is therefore:

H3: MPs are more responsive to immigrant-origin citizens' interests when they sit for leftleaning parties on migrant-related committees as compared to right-leaning MPs or MPs who sit for left-leaning MPs on other committees (H3).

Proponents of electoral system effects, by contrast, would argue that MPs' incentives to cultivate a collective party reputation are stronger under closed-list PR than under SMD elections. Thus a fourth hypothesis is:

H4: The effect of membership in a migrant-related committee is stronger for left-wing MPs elected in the PR tier than for left-wing MPs elected in the SMD tier (H4).

\section{Data and Methods}

\section{Measuring Substantive Representation in Parliamentary Questions}

To test the hypotheses laid out in the previous section, we follow previous research in the field and draw on parliamentary questions (PQs) for written answer (Schriftliche Fragen) as indicators of substantive representation (Aydemir and Vliegenthart 2016; Saalfeld 2011; Saalfeld and Bischof 2013; Wüst 2014a). PQs are well suited to deal with our research question, because they indicate MPs' personal efforts to represent the interests of disadvantaged immigrant groups. Other readily available legislative activities, for example speeches or roll call votes, are strictly control by the PPG leadership, especially in a strongly

party-controlled parliament like the Bundestag (Depauw and Martin 2009; Proksch and Slapin 2015). In comparison, PQs are among the least party controlled parliamentary activities. Therefore, MPs can use them relatively freely to raise the attention of the government to certain issues, to acquire information from the bureaucracy or to claim credit for their PQs in 
their websites, social media or local newspapers (Keh 2015; Martin 2011a, 2011b; Rozenberg and Martin 2011; Russo and Wiberg 2010).

While it remains relatively undisputed that PQs can serve MPs for the purpose of cultivating local voter support (Fernandes, Leston-Bandeira, and Schwemmer 2017; Martin 2011b; Russo 2011; Saalfeld 2011), it is not as common to use PQs as a measure of MPs' responsiveness to the demands of PPGs (but see Bailer 2011; Otjes and Louwerse 2018). However, the fact that the usage of PQs is less constrained by the PPG leadership is not to say that MPs cannot use PQs to please the demands of their PPG leaderships. Rather, PPG leaderships should appreciate MPs' questioning activities. One of the many functions of PQs is information acquisition in order to reduce the knowledge asymmetry vis-à-vis government departments (Russo and Wiberg 2010). This applies especially to PPGs in the opposition, but also to PPGs in government coalitions, for example to keep tabs on the government departments held by coalition partners. In this regard, information is power and MPs' questioning behaviour can serve PPGs as an important source of information retrieval. Therefore, MPs can use PQs to please this demand. However, in difference to other legislative activities, for example speeches or roll call voting, MPs can choose to cater their PPG leaderships with PQs, but will not be immediately punished if a PQ is aimed at cultivating the support of other principals, for example local voters.

Consequently, we compiled all 20,130 PQs tabled by individual MPs in the $17^{\text {th }}$ German Bundestag. In order to identify PQs tabled on behalf of disadvantaged immigrant groups, we focus on the representation of their objective interests rather than on the representation of their subjective interests (for a detailed discussion see Swain 1993:6). That is, PQs are understood to be substantively representative if they raise attention to immigrants' unequal living conditions, for example in terms of level of income, physical well-being or employment status, and/or demand the integration of immigrant-origin residents into German society. 
Integration refers here, according to Alba and Foner, to processes that increase the opportunities of immigrants and their descendants in major institutions such as the educational and political system and the labour and housing market (Alba and Foner 2015:5). In order to identify PQs tabled on behalf of disadvantaged immigrant groups, herein called integration-related $P Q s$, we combine human and dictionary-based machine coding. A detailed description of the text coding procedure and its validation, the final list of key words, as well as two examples of such questions are provided in the appendix A1 and A2 to this paper. Based on this coding, the final measure of our dependent variables is the count of integrationrelated PQs per MP.

\section{Independent and Control Variables}

We measure the magnitude of the local demand of immigrant-origin citizens as the share of foreign nationals in the local district and connect this information to all MPs who are running in the election as SMD tier candidates. Thus, all dually nominated MPs are linked to the constituencies in which they were selected to run as SMD tier candidates. PR tier legislators who did not run as a candidate in a district race (15 out of 652 legislators overall which equals $2.3 \%$ ) were excluded from the analysis. Of course, using the percentage of foreign nationals as a proxy for the immigrant-origin electorate at the constituency-level is not ideal. Nevertheless, it is the only immigrant-related indicator available at the constituency-level, and given it is highly correlated $(\mathrm{r}=0.78)$ with the group of naturalised residents of immigrantorigin at the level of differently drawn administrative districts (Wüst 2014b) we take this indicator as a reasonable approximation of the immigrant-origin electorate. The difference between SMD and PR tier MPs is captured in a dummy variable which takes values of one for SMD MPs. Party differences are captured in a set of five dummy variables for each PPG respectively, and also in a dummy for the simple left/right distinction, in which we categorise 
the CDU/CSU and the FDP as right-wing parties and the SPD, Greens and The Left as leftwing parties. For the purpose of identifying migrant-related committees, we rely on a modified categorisation of the dichotomous categorisation scheme proposed by Wüst (Wüst $2011)^{1}$.

In order to test whether the theoretical framework proposed in this article contributes significantly to established explanations, we also add a control variable for the effect of descriptive representation as the main focus of previous research. We identified all MPs as being of immigrant-origin $(n=24)$ if they were born with a foreign nationality or if one of the respective person's parents was born with a foreign nationality. In addition to that, we control for the total number of $P Q s$ asked per MP. Since the extent to which PQs are used overall should depend on MPs' government or opposition status as well as on their seniority and career stages (Bailer and Ohmura 2017), we control for these factors implicitly when including this variable. Table 1 provides a descriptive overview of all variables.

Table 1: Descriptives

\begin{tabular}{lcccc}
\hline & Min & Max & $\begin{array}{c}\text { Mean / } \\
\text { Share }\end{array}$ & SD \\
\hline No. of integration-related PQs & 0 & 52 & 0.83 & 3.86 \\
\% Foreign Nationals in District & 0.01 & 0.28 & 0.09 & 0.05 \\
PR (0) vs. SMD tier(1) & 0 & 1 & 0.47 & - \\
& & & & \\
Party: Right (0) vs. Left (1) & 0 & 1 & 0.46 & - \\
Dummy: CDU/CSU & 0 & 1 & 0.38 & - \\
Dummy: FDP & 0 & 1 & 0.15 & - \\
Dummy: SPD & 0 & 1 & 0.23 & - \\
$\begin{array}{l}\text { Dummy: Greens } \\
\text { Dummy: The Left }\end{array}$ & 0 & 1 & 0.11 & - \\
Other (0) vs. immigrant-related & 0 & 1 & 0.11 & - \\
committee (1) & 0 & 1 & 0.47 & - \\
Native (0) vs. migratory & & & & \\
background (1) & 0 & 1 & 0.04 & - \\
Total no. of PQs & 0 & 196 & 30.68 & 44.58 \\
\hline Observations & 637 & & & \\
\hline
\end{tabular}




\section{Statistical Model}

The empirical modelling strategy must take into account two related methodological aspects.

First, as our unit of analysis is the MP and the dependent variable captures counts of integration-related questions asked per MP, negative-binomial regression models are an appropriate choice. ${ }^{2}$ Second, the number of zeros in our dependent variable amounts to 527 out of 637 or $82.7 \%$. Zeros may be generated according to two different mechanisms. First, an MP decides not to ask a single integration-related PQ. Second, an MP decides not to ask any PQs at all. The latter mechanism is strongly related to the tendency of MPs representing government parties to ask no or only few PQs, while MPs of opposition parties typically ask a lot more PQs. Obviously, a major precondition to the tabling of integration-related questions is that an MP asks PQs at all. In our dataset 399 out of 637 MPs asked at least one PQ, and 110 MPs asked at least one integration-related question.

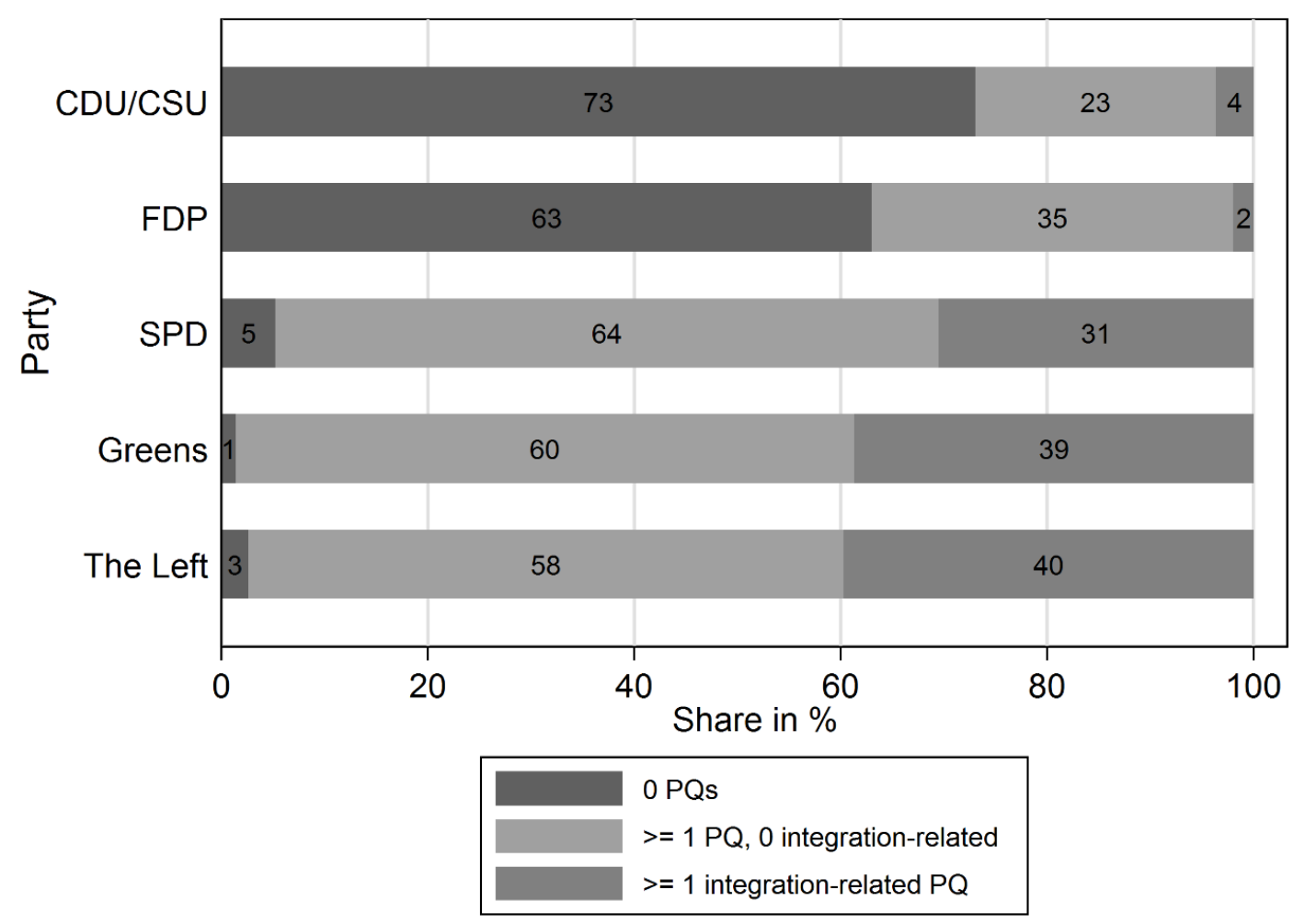

Figure 1. Percentages of MPs by party tabling no $P Q$, at least one $P Q$ but no integration-related $P Q$ s, or at least one integration-related $P Q$. 
Figure $1^{3}$ confirms this suspicion by showing the distribution of MPs who either tabled no PQs, at least one PQ but no integration-related PQs, or at least one integration-related PQ. In comparison to government MPs (CDU/CSU, FDP), members of opposition parties (The Left, SPD, Greens) are more likely to table more PQs overall. This is especially problematic since in the legislative term under study the division between opposition and government was clearcut with regard to the left/ right divide. In order to better disentangle party and opposition effects and better handle the zero-inflation in our dependant variable we fit zero-inflated negative binomial regression models. These models are mixture models that combine two regression equations, a logit model to explain the zero inflation, and a negative binomial model to explain non-zero counts in the dependant variable (Cameron and Trivedi 2013:11176). In order to explain MPs' propensity of asking at least one integration-related PQ, we include the total number of PQs asked by each MP in the inflation equation ${ }^{4}$. Doing so allows us to control for factors that make MPs ask no or few PQs at all, as outlined in the previous section, in the explanations of zero-observations.

\section{Results}

In Table 2 we present the results of four estimated zero-inflated regression models. The models estimate in the count regression equation the effects of the independent and control variables on the number of integration-related PQs MPs have asked throughout the $17^{\text {th }}$ Bundestag. Model 1 includes the local share of foreign nationals and the distinction between MPs' election modes without their interaction (H1), while Model 2 extends the regression model by the interaction between the two variables (H2). The positive and statistically significant coefficient $(\mathrm{p}<0.05)$ of the foreigner share in Model 1 suggests that MPs increase their number of integration-related PQs as the share of foreign nationals rises in their local 
constituencies in which they were selected. Adding the interaction term in Model 2 further shows that this link is not different for MPs elected in the SMD as compared to MPs elected in the PR tier. Here the coefficient for the share of foreign nationals, which stands for the constituency effect of list MPs, is still positive and remains statistically significant at $p<0.1$. However, the coefficient of the interaction term does not come anywhere close to conventional levels of statistical significance $(p=0.691)$.

Table 2: Determinants of the number of integration-related PQs

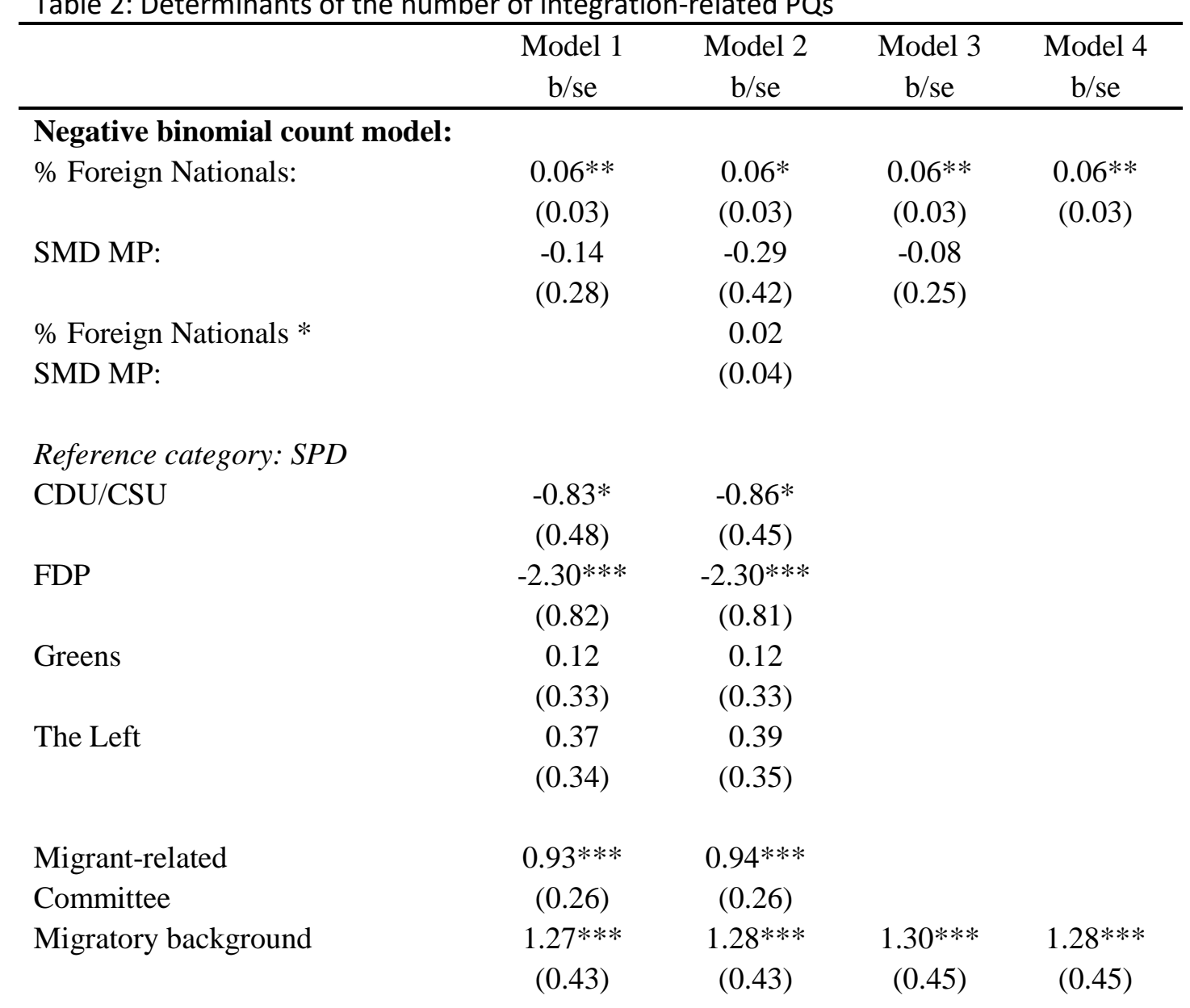

Reference category: Left-wing MP/other committee

Left-wing MP/migrant-related $1.00 * * *$ committee

Right-wing MP/other committee

Right-wing MP/migrant-related committee 
PR/left-wing/ other committee

SMD/left-wing/other committee

PR/left-wing/migrant-related committee

SMD/left-wing/migrant-related committee

SMD/right-wing/other committee

PR/right-wing/migrant-related committee

SMD/right-wing/migrant-related committee Intercept

\section{Zero-inflation logit model:}

Total no. of PQs

$(0.37)$

$(0.40)$

(0.33)

\begin{tabular}{lcccc} 
Total no. of PQs & $-0.07 * * *$ & $-0.07 * * *$ & $-0.07 * * *$ & $-0.07 * * *$ \\
& $(0.02)$ & $(0.02)$ & $(0.02)$ & $(0.02)$ \\
Intercept & $2.17 * * *$ & $2.15 * * *$ & $2.26 * * *$ & $2.24 * * *$ \\
& $(0.42)$ & $(0.41)$ & $(0.40)$ & $(0.40)$ \\
\hline & & & & \\
Intercept alpha & $0.78^{* * *}$ & $0.78 * * *$ & $0.81 * * *$ & $0.80 * * *$ \\
& $(0.21)$ & $(0.21)$ & $(0.20)$ & $(0.20)$ \\
\hline $\mathrm{N}$ & 637 & 637 & 637 & 637 \\
Nonzero N & 110 & 110 & 110 & 110 \\
BIC & 943.76 & 950.07 & 934.57 & 951.91 \\
\hline
\end{tabular}

Note: Zero-inflated negative binomial regression models; Table entries show unstandardized coefficients with robust standard errors in parentheses; ${ }^{*} p<0.10, * *$ $p<0.05, * * * p<0.01$

Figure 2 visualises these effects. Based on model 1, the left-hand panel ${ }^{5}$ shows how the predicted number of integration-related PQs changes when the foreign national share increases from roughly two standard deviations below the mean up to two standard deviations above the mean. The predicted change is roughly one integration-related PQ. While this effect may seem substantially negligible it is important to note that the mean number of integrationrelated PQs for our analysis is only at 0.83 . Moreover, the share of foreign nationals only serves here as a proxy for the size of the immigrant-origin electorate, therefore potentially underestimating the real effect size. Based on model 2, the right-hand panel of figure 2 shows 
the marginal effect of being an SMD MP conditional on the local share of foreign nationals. As can be seen, the election mode does not interact with the size of the immigrant electorate in the constituency. Overall, these findings support $\mathrm{H} 1$ but not $\mathrm{H} 2$.
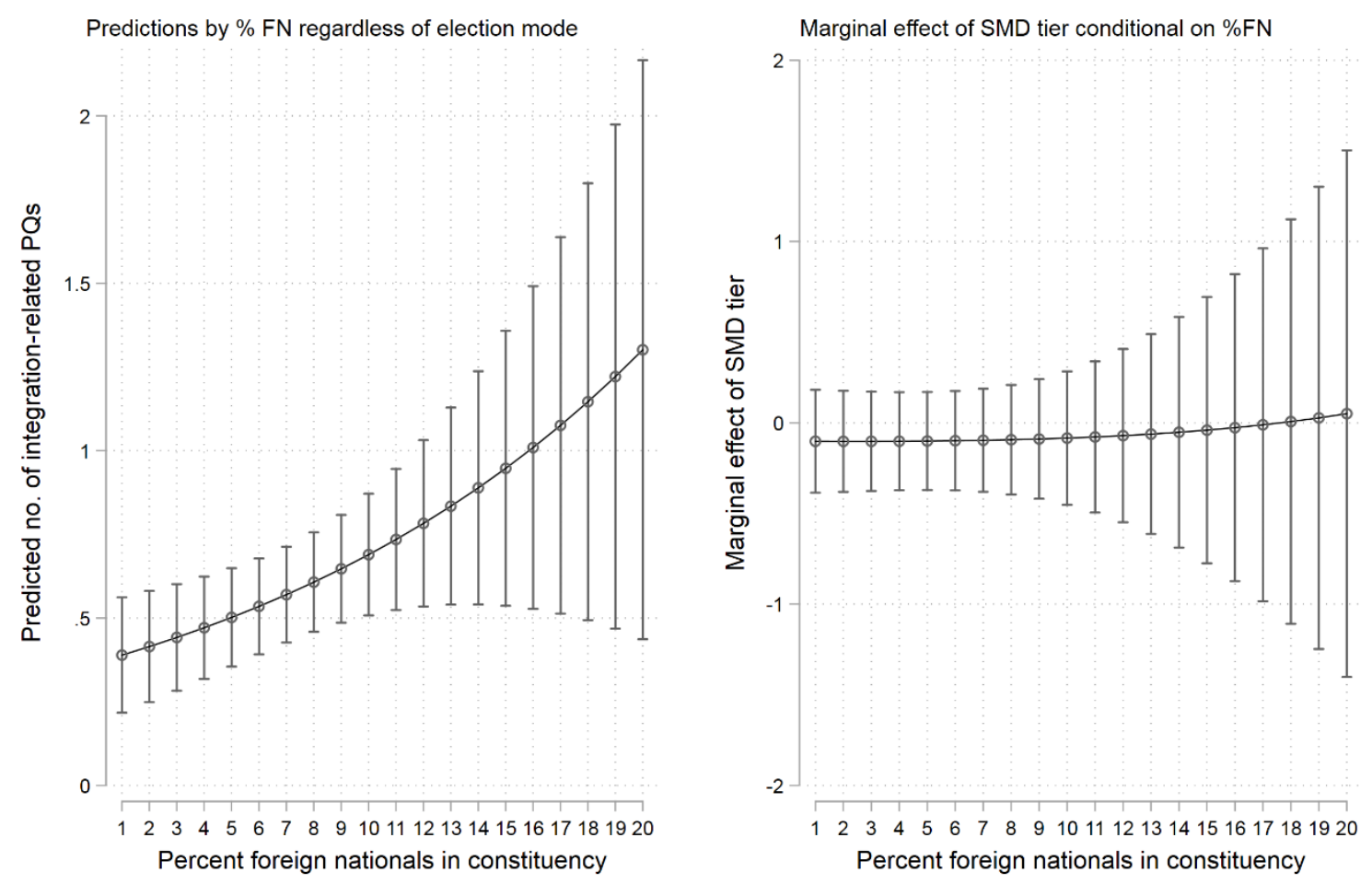

Figure 2. MPs' integration-related PQs in response to local demands with 95\% confidence intervals

Model 3 includes a combination of the two dummy variables measuring, on the one hand, whether MPs represent a left or right-leaning party, and on the other hand, whether they sit on a migrant-related committee or not. The coefficients show that compared to the reference category of left-leaning MPs who do not sit on migrant-related committees, MPs who sit for left-leaning parties on migrant-related committees ask significantly more integration-related PQs. To the contrary, MPs representing right-leaning parties do not differ significantly from the reference category. We visualise this finding in the left panel of Figure 3 as predicted counts of integration-related PQs per committee/party combination. It corroborates $\mathrm{H} 3$, namely that the combination of leftist party ideology and assignment to migrant-related 
committees increases the number of PQs that MPs ask on behalf of disadvantaged immigrant groups.
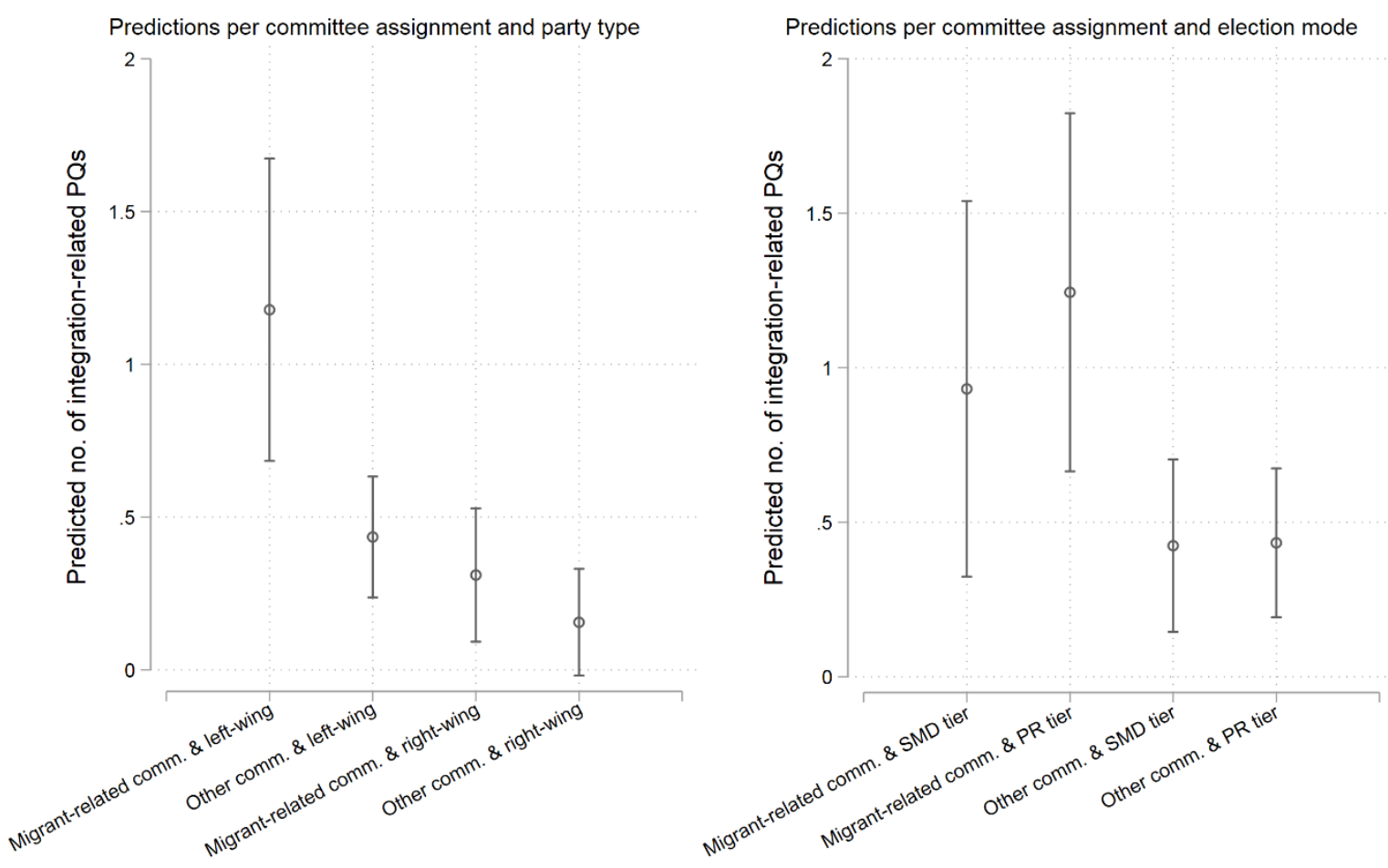

Figure 3. MPs' integration-related PQs in response to PPGs' demands with $95 \%$ confidence intervals

In model 4 we intend to test for whether MPs' election mode can improve the statistical explanation of this variation (H4). For that purpose we turn the previously used two-way combination of variables into a three-way combination by adding MPs' election mode (SMD versus PR tier). Since this regression table is an unwieldy format to assess the model coefficients, we only report these results for transparency reasons, but direct the reader to the visualisation of the predicted counts of integration-related PQs shown in the right panel of Figure 3. In this visualisation, the left/right PPG distinction is held at "left-wing", while MPs committee assignments and election modes vary. As can be seen, the effect of the committee assignment does not vary greatly between MPs' elected in the PR and SMD tier and the confidence intervals are widely overlapping. Therefore, $\mathrm{H} 4$ cannot be supported based on this empirical evidence. 
Furthermore, in all four models it is found that MPs of immigrant-origin are significantly more likely to ask integration-related questions, corroborating findings from previous studies. However, the empirical evidence shows that descriptive representation is only part of the story of immigrants' substantive representation

In summary, our findings suggest, first, that MPs tend to ask more integration-related PQs the more foreign nationals reside in local constituencies where they were selected to run as district candidates. Second, they ask more of those questions when they sit for left-wing parties on committees more likely to deal with matters of immigrants' integration. Third, these relationships exist irrespective of MPs' own national backgrounds and regardless of whether they were elected under SMD or PR electoral rules in Germany's mixed-member system. This conclusion is also supported by a comparison of BIC values across the four models. Model 3, which models the direct effect of the share of foreign nationals in a constituency and the party-committee interaction, turns out to have the lowest BIC value and hence the best model fit.

Our results are robust to different modelling strategies. As robustness checks we refitted the models as standard negative binomial regression models on the whole sample of MPs as well as on a reduced sample of MPs who have asked at least one PQ. The corresponding models are shown in tables A3 and A4 in the appendix and provide the same substantive results as those presented in our main analysis.

\section{Concluding remarks}

Western representative democracies face new challenges due to the pressures of large-scale immigration creating multi-ethnic societies (Bird et al. 2011). Drawing on principal-agent theory, this paper examines how institutional factors shape MPs' responsiveness to the 
disadvantages that immigrants and their descendants face in German society. Arguing that the role of native MPs has been underappreciated in previous research, we conceptualise MPs irrespective of their own national backgrounds as delegates who act based on the instructions of their most important principals: local constituents, party selectorates and PPGs. This analytical perspective constitutes a contrast to the "politics of presence" approach, which sees MPs rather as trustees whose consciousness and personal experiences determine their legislative behaviour (Mansbridge 1999; Phillips 1995). However, we do not seek to belittle previous work based on the trustee conception. Rather, we argue that in order to improve our knowledge of the political representation of disadvantaged immigrant groups, it is fruitful to investigate relevant phenomena through a variety of analytical perspectives.

Drawing on a new dataset which includes a corpus of all 20,130 parliamentary questions (PQs) tabled by individual MPs in the $17^{\text {th }}$ Bundestag, we find that the demands of MPs' principals shape profoundly the substantive representation of disadvantaged immigrant groups in PQs. Moreover, the German institutional context, which confronts MPs with mixed electoral rules, a localised candidate selection process and tightly organised PPGs, allows us further to derive competing hypotheses about the behavioural consequences of these institutional features. Putting these hypotheses to the test, our empirical results provide little support for the idea that differences in electoral rules shape immigrants' substantive representation in MPs' parliamentary questions. However, our findings do suggest, first, that MPs' responsiveness to local concentrations of immigrant-origin citizens hinges on a localised candidate selection method. Second, their responsiveness to the demands of national party bodies to speak on behalf of disadvantaged immigrant groups is a consequence of tightly organised PPGs in the Bundestag.

Taken together, our study makes therefore two important contributions to the literature. First, it shows that our understanding of the substantive representation of immigrant-origin 
minorities can be advanced by conceptualising MPs irrespective of their national backgrounds as delegates of principals inside and outside parliament. Second, this paper outlines also the limits of institutional explanations given the finding that candidate selection rules and legislative organisation are found to outperform electoral rules in their effects on immigrants' substantive representation in MPs' parliamentary questions.

Thus, future research should recognise more strongly the role of native MPs and the factors that affect their legislative behaviour. As long as different immigrant groups remain descriptively underrepresented in national legislatures, native MPs remain the most important vessel for this group's substantive representation. In other words, more research is needed to better understand MPs' legislative behaviour irrespective of their national backgrounds.

In this regard, our study of the German case is a first step. Comparative research conducts would be a valuable extension to the present study in order to deepen our understanding of the consequences of candidate selection and legislative organisation for substantive representation across different electoral system regimes. Moreover, future research may also include other characteristics of MPs' institutional environments. For example, in many party-centred electoral systems national MPs pursue local political careers simultaneously (Fernandes et al. 2017; Russo 2011) or are subject to powerful local party branches in other ways (Tavits 2011). These factors can have the effect that MPs remain responsive to the demands of local concentrations of immigrant-origin citizens despite party-centred electoral rules. Given its parsimony, principal-agent theory should be a useful tool to explore the consequences of these factors in other parliamentary democracies, as well. In this light, the present contribution should be understood as a point of departure for future studies interested in the political representation of immigrants and their descendants in Western democracies. 


\section{SOURCES}

Alba, Richard and Nancy Foner. 2015. Strangers No More: Immigration and the Challenges of Integration in North America and Western Europe. Princeton: Princeton University Press.

Aldrich, John H. 1995. Why Parties? Chicago: University of Chicago Press.

Andeweg, Rudy and Jaques J. A. Thomassen. 2005. "Modes of Political Representation: Toward a New Typology.” Legislative Studies Quarterly 30(4):507-28.

Aydemir, Nermin and Rens Vliegenthart. 2016. “"Minority Representatives' in the Netherlands: Supporting, Silencing or Suppressing?” Parliamentary Affairs 69(1):7392.

Bailer, Stefanie. 2011. “People's Voice or Information Pool? The Role Of, and Reasons For, Parliamentary Questions in the Swiss Parliament.” Journal of Legislative Studies 17(3):302-14.

Bailer, Stefanie and Tamaki Ohmura. 2017. "Exploring, Maintaining, and Disengaging-The Three Phases of a Legislator's Life.” Legislative Studies Quarterly. Retrieved January 28, 2018 (http://doi.wiley.com/10.1111/lsq.12192).

Bird, Karen, Thomas Saalfeld, and Andreas M. Wüst. 2011. "Ethnic Diversity, Political Participation and Representation: A Theoretical Framework.” Pp. 1-22 in The Political Representation of Immigrants and Minorities. Voters, Parties and Parliaments in Liberal Democracies, edited by K. Bird, T. Saalfeld, and A. M. Wüst. London and New York: Routledge.

Bischof, Daniel. 2017. "New Graphic Schemes for Stata: Plotplain and Plottig.” Stata Journal 17(3):748-59. 
Bloemraad, Irene and Karen Schönwälder. 2013. "Immigrant and Ethnic Minority

Representation in Europe: Conceptual Challenges and Theoretical Approaches.” West European Politics 36(3):564-79.

Bundeswahlleiter. 2013. “5,8 Millionen Deutsche Mit Migrationshintergrund Sind Wahlberechtigt.” Retrieved March 9, 2016

(https://www.bundeswahlleiter.de/de/bundestagswahlen/BTW_BUND_13/presse/W1301 3_Wahlberechtigte_Migrationshintergrund.html).

Cameron, Adrian C. and P. K. Trivedi. 2013. Regression Analysis of Count Data. Cambridge: Cambridge University Press.

Carey, John M. 2009. Legislative Voting and Accountability. Cambridge: Cambridge University Press.

Carey, John M. and Matthew Soberg Shugart. 1995. "Incentives to Cultivate a Personal Vote: A Rank Ordering of Electoral Formulas.” Electoral Studies 14(4):417-39.

Converse, Philip E. and Roy Pierce. 1986. Political Representation in France. Cambridge: MA: Belknap Press.

Cox, Gary W. 2006. "The Organization of Democratic Legislatures.” Pp. 141-61 in The Oxford Handbook of Political Economy, edited by B. R. Weingast and D. A. Wittman. Oxford: Oxford University Press.

Cox, Gary W. and Mathew D. McCubbins. 1993. Legislative Leviathan. Party Government in the House. Berkeley: University of California Press.

Crisp, B. F. 2007. "Incentives in Mixed-Member Electoral Systems: General Election Laws, Candidate Selection Procedures, and Cameral Rules." Comparative Political Studies 40(12):1460-85. 
Dahl, Robert A. 1971. Polyarchy: Participation and Opposition. New Haven: Yale University Press.

Damgaard, Erik. 1995. "How Parties Control Committee Members.” Pp. 308-24 in Parliaments and Majority Rule in Western Europe, edited by H. Döring. Frankfurt am Main: Campus Verlag.

Depauw, Sam and Shane Martin. 2009. "Legislative Party Discipline and Cohesion in Comparative Perspective.” Pp. 103-20 in Intra-Party Politics and Coalition Governments in Parliamentary Democracies, edited by D. Giannetti and K. R. Benoit. London: Routledge.

Detterbeck, Klaus. 2016. "Candidate Selection in Germany: Local and Regional Party Elites Still in Control?" American Behavioral Scientist 60(7):837-52.

Die Beauftragte der Bundesregierung für Migration, Flüchtlinge und Integration. 2016. 11. Bericht Der Beauftragten Der Bundesregierung Für Migration, Flüchtlinge Und Integration - Teilhabe, Chancengleichheit Und Rechtsentwicklung in Der Einwanderungsgesellschaft Deutschland.

Fernandes, Jorge M., Cristina Leston-Bandeira, and Carsten Schwemmer. 2017. "Election Proximity and Representation Focus in Party-Constrained Environments." Party Politics (July 2016):135406881768995.

Ferrara, Federico, Erik S. Herron, and Misa Nishikawa. 2005. Mixed Electoral Systems. Contamination and Its Consequences. New York: Palgrave Macmillan.

Gallagher, Michael. 1988. "Introduction.” Pp. 1-19 in Candidate Selection in Comparative Perspective. The Secret Garden of Politics, edited by M. Gallagher and M. Marsh. London: Sage. 
Hainmueller, Jens and Holger Lutz Kern. 2008. "Incumbency as a Source of Spillover Effects in Mixed Electoral Systems: Evidence from a Regression-Discontinuity Design.” Electoral Studies 27(2):213-27.

Hanmer, Michael J. and Kerem O. Kalkan. 2013. "Behind the Curve: Clarifying the Best Approach to Calculating Predicted Probabilities and Marginal Effects from Limited Dependent Variable Models.” American Journal of Political Science 57(1):263-77.

Hänni, Miriam. 2017. "Presence, Representation, and Impact: How Minority MPs Affect Policy Outcomes." Legislative Studies Quarterly 42(1):97-130.

Ismayr, Wolfgang. 2012. Der Deutsche Bundestag. Wiesbaden: VS Verlag für Sozialwissenschaften.

Karlsen, Rune and Hanne M. Narud. 2013. "Nominations, Campaigning and Representation: How the Secret Garden of Politics Determines the Style of Campaigning and Roles of Representation.” Pp. 77-101 in Between-Election Democracy. The Representative Relationship after Election Day, edited by P. Essaiasson and H. M. Narud. Colchester: ECPR Press.

Keh, Julia Frederike. 2015. "The Centralisation of Parliamentary Policy Statements in Western European Parliaments.” West European Politics 38(5):1086-1105.

Manow, Philip. 2013. "Mixed Rules, Different Roles? An Analysis of the Typical Pathways into the Bundestag and of MPs' Parliamentary Behaviour.” The Journal of Legislative Studies 19(3):287-308.

Mansbridge, Jane. 1999. "Should Blacks Represent Blacks and Women Represent Women? A Contingent 'Yes."' The Journal of Politics 61(3):628-57.

Martin, Shane. 2011a. "Parliamentary Questions, the Behaviour of Legislators, and the 
Function of Legislatures: An Introduction.” The Journal of Legislative Studies 17(3):259-70.

Martin, Shane. 2011b. “Using Parliamentary Questions to Measure Constituency Focus: An Application to the Irish Case." Political Studies 59(2):472-88.

Martin, Shane. 2014. "Why Electoral Systems Don’t Always Matter: The Impact of 'megaSeats' on Legislative Behaviour in Ireland." Party Politics 20(3):467-79.

Mattson, Ingvar and Kaare Strøm. 1995. "Parliamentary Committees.” Pp. 249-307 in Parliaments and Majority Rule in Western Europe, edited by H. Doring. Frankfurt am Main: Campus Verlag.

Messina, Anthony M. 2007. The Logics and Politics of Post-WWII Migration to Western Europe. Cambridge: Cambridge University Press.

Miller, Bernhard and Christian Stecker. 2008. "Consensus by Default? Interaction of Government and Opposition Parties in the Committees of the German Bundestag." German Politics 17(3):305-22.

Mitchell, Paul. 2000. "Voters and Their Representatives: Electoral Institutions and Delegation in Parliamentary Democracies.” European Journal of Political Research 37:335-51.

Moser, Robert G. and Ethan Scheiner. 2012. Electoral Systems and Political Context. How the Effects of Rules Vary Across New and Established Democracies. Cambridge: Cambridge University Press.

Müller, Wolfgang C. 2000. "Political Parties in Parliamentary Democracies: Making Delegation and Accountability Work.” European Journal of Political Research 37(3):309-33.

OECD and EU. 2015. Indicators of Immigrant Integration 2015: Settling In. Paris: OECD 
Publishing.

Otjes, Simon and Tom Louwerse. 2018. "Parliamentary Questions as Strategic Party Tools.” West European Politics 41(2):496-516.

Phillips, Anne. 1995. The Politics of Presence. Oxford: Clarendon Press.

Pitkin, Hanna Fenichel. 1967. The Concept of Representation. Berkeley: University of California Press.

Preece, Jessica Robinson. 2014. "How The Party Can Win in Personal Vote Systems: The ‘Selectoral Connection' and Legislative Voting in Lithuania.” Legislative Studies Quarterly 39(2):147-67.

Proksch, Sven-Oliver and Jonathan Slapin. 2015. The Politics of Parliamentary Debate. Cambridge: Cambridge University Press.

Rahat, Gideon and Reuven Y. Hazan. 2001. "Candidate Selection Methods - An Analytical Framework." Party Politics 7(3):297-322.

Rozenberg, Olivier and Shane Martin. 2011. "Questioning Parliamentary Questions.” The Journal of Legislative Studies 17(3):394-404.

Russo, Federico. 2011. "The Constituency as a Focus of Representation: Studying the Italian Case through the Analysis of Parliamentary Questions.” The Journal of Legislative Studies 17(3):290-301.

Russo, Federico and Matti Wiberg. 2010. "Parliamentary Questioning in 17 European Parliaments: Some Steps towards Comparison.” The Journal of Legislative Studies 16(2):215-32.

Saalfeld, Thomas. 2011. "Parliamentary Questions as Instruments of Substantive 
Representation: Visible Minorities in the UK House of Commons, 2005-10." The Journal of Legislative Studies 17(3):271-89.

Saalfeld, Thomas and Daniel Bischof. 2013. "Minority-Ethnic MPs and the Substantive Representation of Minority Interests in the House of Commons, 2005-2011.” Parliamentary Affairs 66(2):305-28.

Saalfeld, Thomas and Kaare W. Strøm. 2014. "Political Parties and Legislators.” Pp. 371-98 in Oxford Handbook of Legislative Studies. Oxford: Oxford University Press.

Strøm, Kaare. 1997. "Rules, Reasons and Routines: Legislative Roles in Parliamentary Democracies.” Pp. 155-74 in Members of Parliament in Western Europe: Roles and Behaviour, edited by W. C. Müller and T. Saalfeld. London: Frank Cass.

Strøm, Kaare. 1998. "Parliamentary Committes in European Democracies.” Journal of Legislative Studies 4(1):21-59.

Strøm, Kaare. 2000. "Delegation and Accountability in Parliamentary Democracies." European Journal of Political Research 37(3):261-89. Retrieved (http://dx.doi.org/10.1111/1475-6765.00513).

Swain, Carol. 1993. Black Faces, Black Interests - The Representation of African Americans in Congress. London: Harvard University Press.

Tavits, Margit. 2011. "Power within Parties: The Strength of the Local Party and MP Independence in Postcommunist Europe.” American Journal of Political Science 55(4):923-36.

Wüst, Andreas M. 2011. "Migrants as Parliamentary Actors in Germany.” Pp. 250-65 in The Political Representation of Immigrants and Minorities. Voters, Parties and Parliaments in Liberal Democracies, edited by K. Bird, T. Saalfeld, and A. M. Wüst. 
Wüst, Andreas M. 2014a. “A Lasting Impact? On the Legislative Activities of ImmigrantOrigin Parliamentarians in Germany.” Journal of Legislative Studies (May):37-41.

Wüst, Andreas M. 2014b. "Immigration into Politics: Immigrant-Origin Candidates and Their Success in the 2013 Bundestag Election.” German Politics \& Society 32(3):1-15.

\section{Notes}

\footnotetext{
${ }^{1}$ Immigrant-related committees are labour and social affairs; education and research; family, elderly and women; domestic affairs; culture and media; human rights; economic development; petitions; and the investigation committee on the fascist terror of the "Nationalsozialistischer Untergrund" (NSU).

${ }^{2}$ We chose a negative binomial model as diagnostics for a poisson model indicated overdispersion. Vuong tests further provided strong support for the use of zero-inflated mixture models.

${ }^{3}$ All figures shown in this paper were generated using the Stata scheme plotplain (Bischof 2017).

${ }^{4}$ We tested other specifications of the zero -inflation equation, including other variables used in the count equation. However, since these variables did not turn out to be significant and further increased the complexity of the models without improving their explanatory power indicated by a growing BIC value (Bayesian Information Criterion), we decided against their inclusion.

${ }^{5}$ Following suggestions of Hanmer and Kalkan, all predicted values of the dependent variable and marginal effects shown in Figures 2 and 3 are based on the empirical observed values of remaining variables in the respective models (Hanmer and Kalkan 2013).
} 


\section{Appendix}

\section{A1: Measuring "integration-related” PQs}

The texts of German PQs were extracted from official online archives of the Bundestag using Python programming scripts. All files were available as PDF documents and were converted to raw text. Subsequently, several string matching procedures were used to isolate questions and subsequently match them with MP-level information.

The measurement goal is to identify PQs that raise attention to and demand the improvement of the living conditions of immigrants and their descendants. It is important to note that we do not intend to capture sceptical positions on the integration of immigrant-origin residents, i.e. content that relates to the protection of German national identity or expresses reservations against the integration of immigrants and multicultural society. In other words, our measure should not be mistaken as a measure of saliency or positioning on a pro- vs. anti-immigrant continuum.

The following two translated examples illustrate how parliamentary written questions are used by MPs in order to raise attention to and demand the improvement of the living conditions of immigrants and their descendants.

„How does the government justify the Federal Office for Migration and Refugees recent announcement to cut the budget for integration courses in the light of the CDU, CSU and FPDs ' coalition agreements ' plan to qualitatively and quantitatively upgrade those courses?" (PQ tabled by Aydan Özoğuz, SPD, May 7th 2010) 
„... how does the government want to ensure that the Federal Employment Office will bring residents with a migratory background into vocational training in similar proportions in their respective age groups as compared to Germans." (PQ tabled by Mechthild Rawert, SPD, March 18th 2011)

Ideally, in order to identify integration-related PQs, every single question in our corpus would be inspected qualitatively to determine whether it addresses immigrants' disadvantages in German society or not. As this is not feasible for over 20,000 questions we combine human and machine coding to identify integration-related PQs. The procedure involved four steps. In a first step we pre-defined a list of terms which have been manually extracted from the minutes of a parliamentary debate in which integration-related issues were discussed ${ }^{5}$. We also added other terms that we gathered from comprehensive qualitative inspections of the PQs. We then used this list of terms to filter the corpus. If, for example, a PQ includes the term "Migrationshintergrund" (German for "migratory background") or any other term in the list, this PQ would remain in our filtered corpus. A PQ without any terms on the list would be excluded from the corpus.

In a second step, we combined this filtered corpus with a random sample of remaining, nonfiltered PQs. Two hand coders were familiarised with our definition of substantive representation and then were asked to classify each question as either integration-related or not $^{5}$. The intercoder-reliability in form of Cohen's Kappa (Cohen 1960) between human coders was 0.79 . All coding disagreements were discussed and recoded after consensus accordingly. Additionally, from each validated question, our hand-coders again collected specific key terms which indicate that the question is integration-related. We updated the key term list accordingly. 
In a third step we used the hand-coded corpus to test our updated key term list for the identification of integration-related PQs. By using the updated list of key terms ${ }^{5}, 82 \%$ of all questions in our validated corpus were classified correctly ${ }^{5}$. In a fourth step we applied our updated key term list to all 20,130 PQs, identifying a total of 869 potentially integrationrelated questions in the whole corpus.

One concern with key term-based textual analyses is its susceptibility to falsely capturing irrelevant documents (false positives), while at the same time failing to capture relevant documents (false negatives). In order to keep such bias at a minimum, we inspected in a final step all 869 positives qualitatively in order to discard false positives, which left us with a total of 544 PQs as a final measure of integration-related PQs. This amounts to $2.7 \%$ of all PQs in our corpus.

Concerns regarding false negatives cannot be quantified to the same extent, but we are confident that this does not pose too great a problem to our measurement, given that we have included a random subset of the unfiltered corpus in our validation approach in step 2. Nevertheless, to be fair, we cannot completely rule out that the captured number of integration-related PQs constitutes an underestimation of the real number of integrationrelated PQs in the analysed text corpus. 
A2: Final term dictionary to identify questions

abgeschoben, abschiebehaftbedingungen, abschiebestopps, abschiebung, abschiebungen, altübersiedler, aufenthaltstitel, antidiskriminierungsrichtlinie, antidiskriminierungsstelle, arbeitserlaubnis, aslybewerberleistungsbezug, assoziationsrecht, asyl, asylantrag, asylantragstellern, asylanträge, asylbewerber, asylbewerberinnen, asylbewerberleistungsbezug, asylbewerberleistungsgesetz, asylbewerberleistungsgesetzes, asylbewerberleistungsgestz, asylbewerberleisungsgesetz, asylbewerbern, asylbewerbers, asylblg, asylsuchende, asylsuchenden, asylsuchendenzahlen, asylsuchender, asylsystem, asylsystems, asylverfahren, asylverfahrenrichtlinie, asylverfahrensgesetz, asylverfahrensgesetzes, asylverfahrensrecht, asylverfahrensrichtlinie, asylverfahrungsgesetz, aufenthaltgesetz, aufenthaltsstatus, aufenthaltserlaubnis, aufenthaltserlaubnisse, aufenthaltserlaubnis, aufenthaltsgesetz, aufenthaltsgesetze, aufenthaltsgesetzes, aufenthaltsgestaltung, aufenthaltsgewährung, aufenthaltspapiere, aufenthaltsrecht, aufenthaltstitel, ausländer, ausländerbeschäftigungsrecht, ausländerförderung, ausländerjagdschein, ausländerzentralregister, ausländischer, aussiedler, balkanflüchtlinge, bleiberechtsregelung, bleibeberechtigung, bürgerkriegsflüchtlinge, bürgerkriegsflüchtlingen, diskriminierung, doppelstaatlers, drittstaatangehörige, drittstaatsangehörige, drittstaatsangehörigen, dublin-ii, dublinüberstellungsverfahren, ehegattennachzug, einbürgerung, einbürgerungstest, einbürgerungstests, einbürgerungsverhalten, eingebürgert, einreiseerlaubnis, einreisevisum, einwanderern, einwanderungsgruppen, eu-aufnahmerichtlinie, eu-aufnahmerichtlinien, fachkräfteanwerbung, familiennachzug, familienzusammenführung, familienzusammenführungsrichtlinen, familienzusammenführungsrichtlinie, flüchtlinge, flüchtlingen, flüchtlingselend, flüchtlingskonvention, flüchtlingslager, frontex, grenzsicherug, grenzübergangsstellen, herkunftsfamilie, herkunftsland, herkunftsstaaten, integration, integrationsansprüche, integrationsarbeit, integrationscoaching, integrationsfördernd, integrationsförderung, integrationsgipfel, integrationsherausforderungen, integrationskurs, integrationskursbeteiligung, integrationskurse, integrationskursen, integrationsleistung, integrationsleistungen, integrationsministerkonferenz, integrationspolitik, integrationspolitisch, integrationsprogramm, integrationsprogramms, integrationsprojekte, integrationssprachkursleiter, integrationstest, 
integrationsunwillig, integrationsverordnung, integriert, interkulturelle bildung, intgegrationsprojekte, islam, jugendintegrationskurse, jugendmigrationsdienst, jugendmigrationsdienstes, migranten, migrantinnen, migration, migrationsabkommen, migrationsbiographie, migrationshintergrund, migrationshintergrund, migrationshintergrundes, minderheitsangehoerige, minderheitsangehörige, immigranten, optionskind, optionskinder, optionspflicht, optionspflichtige, rassismus, resettlementprogramms, roma-minderheit, rückführungsabkommen, rückführungsentscheidungen, rücknahmeabkommen, rückübernahmeabkommen, rückübernahmeabkommens, rücküberstellung, sammelunterkünfte, sammelunterkünften, scheineheverdachts, scheineheverdachtsfälle, sprachförderung, sprachkurs, sprachkurse, sprachkursen, sprachtest, spätaussiedler, staatenlose, staatsangehörigkeit, staatsangehörigkeitsgesetz, staatsangehörigkeitsrecht, staatsbürgerschaft, visa, visagebühren, visapflicht, visavergabe, visum, visumantrags, visumanträge, visumbefreiung, visumfreiheit, visumgebühren, visums, visumsanträge, visumsbefreiung, visumsfreiheit, visumsgebühren, visumspflicht, visumverfahren, zugewandert, zuwanderer, zuwanderern, zuwanderung

A3: Robustness Check 1 - Negative binomial regression models

\begin{tabular}{|c|c|c|c|c|}
\hline & $\begin{array}{c}\text { Model } 1 \\
\text { b/se }\end{array}$ & $\begin{array}{c}\text { Model } 2 \\
\text { b/se }\end{array}$ & $\begin{array}{c}\text { Model } 3 \\
\text { b/se }\end{array}$ & $\begin{array}{c}\text { Model } 4 \\
\text { b/se }\end{array}$ \\
\hline$\%$ Foreign Nationals: & $\begin{array}{c}0.06^{* * * *} \\
(0.02)\end{array}$ & $\begin{array}{c}0.06^{* *} \\
(0.03)\end{array}$ & $\begin{array}{c}0.07 * * * * \\
(0.02)\end{array}$ & $\begin{array}{c}0.06^{* * * *} \\
(0.02)\end{array}$ \\
\hline District MP: & $\begin{array}{l}-0.24 \\
(0.30)\end{array}$ & $\begin{array}{l}-0.33 \\
(0.47)\end{array}$ & $\begin{array}{l}-0.06 \\
(0.26)\end{array}$ & \\
\hline$\%$ Foreign Nationals * District MP: & & $\begin{array}{c}0.01 \\
(0.05)\end{array}$ & & \\
\hline Reference category: SPD & & & & \\
\hline $\mathrm{CDU} / \mathrm{CSU}$ & $\begin{array}{c}-1.26 * * * \\
(0.42)\end{array}$ & $\begin{array}{c}-1.26 * * * \\
(0.43)\end{array}$ & & \\
\hline FDP & $\begin{array}{c}-2.76^{* * *} * \\
(0.78)\end{array}$ & $\begin{array}{c}-2.76 * * * \\
(0.78)\end{array}$ & & \\
\hline Greens & $\begin{array}{c}0.06 \\
(0.35)\end{array}$ & $\begin{array}{c}0.06 \\
(0.35)\end{array}$ & & \\
\hline The Left & $\begin{array}{l}-0.07 \\
(0.31)\end{array}$ & $\begin{array}{l}-0.05 \\
(0.31)\end{array}$ & & \\
\hline Migrant-related committee & $\begin{array}{c}1.04 * * * \\
(0.24)\end{array}$ & $\begin{array}{c}1.04 * * * \\
(0.24)\end{array}$ & & \\
\hline Migratory background & $\begin{array}{c}1.24 * * * \\
(0.38)\end{array}$ & $\begin{array}{c}1.25^{* * * *} \\
(0.38)\end{array}$ & $\begin{array}{c}1.24 * * * \\
(0.38)\end{array}$ & $\begin{array}{c}1.27 * * * * \\
(0.39)\end{array}$ \\
\hline
\end{tabular}


Reference category: Left-wing

MP/other committee

Left-wing MP/migrant-related $1.12 * * *$ committee

Right-wing MP/other committee

Right-wing MP/migrant-related $-0.29$ committee

Reference category: PR/right-

wing/other committee

PR/left-wing/ other committee

SMD/left-wing/other committee

PR/left-wing/migrant-related

committee

SMD/left-wing/migrant-related

committee

SMD/right-wing/other committee

$\mathrm{PR} /$ right-wing/migrant-related

SMD/right-wing/migrant-related committee

\begin{tabular}{lcccc} 
Total no. of PQs & $0.02 * * *$ & $0.02 * * *$ & $0.02 * * *$ & $0.02 * * *$ \\
& $(0.00)$ & $(0.00)$ & $(0.00)$ & $(0.00)$ \\
Intercept & $-2.48 * * *$ & $-2.44 * * *$ & $-2.63 * * *$ & $-5.13 * * *$ \\
& $(0.40)$ & $(0.42)$ & $(0.39)$ & $(1.09)$ \\
\hline \multirow{3}{*}{ Intercept alpha } & & & & \\
& $1.18 * * *$ & $1.18 * * *$ & $1.20 * * *$ & $1.17 * * *$ \\
\hline $\mathrm{N}$ & $(0.16)$ & $(0.16)$ & $(0.17)$ & $(0.17)$ \\
$\mathrm{BIC}$ & 637 & 637 & 637 & 637 \\
\hline
\end{tabular}

Note: Negative binomial regression models; Table entries show unstandardised coefficients with robust standard errors in parentheses; $* \mathrm{p}<0.10, * * \mathrm{p}<0.05, * * * \mathrm{p}<0.01$

A4: Robustness Check 2 - Negative binomial regression models only for MPs who asked at least one question

\begin{tabular}{lcccc}
\hline & $\begin{array}{c}\text { Model 1 } \\
\mathrm{b} / \mathrm{se}\end{array}$ & $\begin{array}{c}\text { Model 2 } \\
\mathrm{b} / \mathrm{se}\end{array}$ & $\begin{array}{c}\text { Model 3 } \\
\mathrm{b} / \mathrm{se}\end{array}$ & $\begin{array}{c}\text { Model } 4 \\
\mathrm{~b} / \mathrm{se}\end{array}$ \\
\hline \% Foreign Nationals: & & & & \\
& $0.04 * * *$ & 0.04 & $0.05^{* * * *}$ & $0.05^{* * *}$ \\
District MP: & $(0.02)$ & $(0.02)$ & $(0.02)$ & $(0.02)$ \\
\% Foreign Nationals * District MP: & -0.06 & -0.26 & 0.04 & \\
& $(0.27)$ & $(0.44)$ & $(0.24)$ & \\
& & 0.02 & &
\end{tabular}


Reference category: SPD

$\mathrm{CDU} / \mathrm{CSU}$

FDP

Greens

The Left

Migrant-related committee

Migratory background $\begin{array}{ll}-0.30 & -0.31\end{array}$

(0.39) (0.40)

$-1.66 * * * \quad-1.66 * * *$

$(0.72) \quad(0.72)$

$0.14 \quad 0.15$

$(0.30) \quad(0.30)$

$-0.14 \quad-0.11$

$(0.30) \quad(0.31)$

$0.69 * * * \quad 0.69 * * *$

$(0.22) \quad(0.22)$

$1.07 * * * \quad 1.10 * * * \quad 1.10 * * * \quad 1.13 * * *$

$\begin{array}{llll}(0.28) & (0.28) & (0.28) & (0.28)\end{array}$

Reference category: Left-wing MP/other committee

Left-wing MP/migrant-related committee

$0.71 * * *$

$-0.70$

$(0.49)$

0.14

Right-wing MP/migrant-related

Reference category: PR/right-

wing/other committee

$\mathrm{PR} /$ left-wing/ other committee

SMD/left-wing/other committee

PR/left-wing/migrant-related committee

SMD/left-wing/migrant-related committee

SMD/right-wing/other committee

PR/right-wing/migrant-related committee

SMD/right-wing/migrant-related committee

Total no. of PQs

$$
\begin{array}{cc}
0.07 * * * & 0.07 * * * \\
(0.01) & (0.01) \\
-2.04 * * * & -1.96 * * *
\end{array}
$$

Intercept

\begin{tabular}{lcccc} 
INTERCEPT alpha & $0.74 * * *$ & $0.74 * * *$ & $0.77 * * *$ & $0.74 * * *$ \\
& $(0.17)$ & $(0.17)$ & $(0.17)$ & $(0.18)$ \\
\hline $\mathrm{N}$ & 387 & 387 & 387 & 387 \\
$\mathrm{BIC}$ & 872.64 & 878.28 & 864.64 & 878.21 \\
\hline
\end{tabular}

Note: Negative binomial regression models; Table entries show unstandardised coefficients with robust standard errors in parentheses; * $\mathrm{p}<0.10, * * \mathrm{p}<0.05, * * * \mathrm{p}<0.01$ 


\section{Appendix Sources}

Cohen, Jacob. 1960. "A Coefficient of Agreement for Nominal Scales.” Educational and Psychological Measurement 20(1): 37-46.

Deutscher Bundestag. 2010. Stenografischer Bericht. 68. Sitzung (17/68). 28 October 2010. http://dip21.bundestag.de/dip21/btp/17/17068.pdf.

Grimmer, Justin, and Brandon M. Stewart. 2013. "Text as Data: The Promise and Pitfalls of Automatic Content Analysis Methods for Political Texts.” Political Analysis 1(1-31). 